\title{
PEMBERDAYAAN MASYARAKAT MELALUI PELATIHAN TATA KECANTIKAN KULIT PADA PROGRAM PENINGKATAN PENDIDIKAN DAN PENDAPATAN KELUARGA DI KOTA TASIKMALAYA \\ ${ }^{1}$ Adang Danial, ${ }^{2}$ Lesi Oktiwanti, ${ }^{3}$ Dede Nurul Qomariah 1,2,3 Jurusan Pendidikan Masyarakat, Fakultas Keguruan dan Ilmu Pendidikan, Universitas Siliwangi adangdanial58@yahoo.com
}

\begin{abstract}
ABSTRAK
Pemberdayaan masyarakat melalui pelatihan tata kecantikan kulit ini bertujuan untuk meningkatkan pengetahuan dan keterampilan masyarakat di Kota Tasikmalaya melalui program peningkatan pendidikan dan pendapatan keluarga (P4K). Hasil penelitian menunjukkan bahwa hampir sebagian besar peserta pelatihan mengharapkan pelatihan ini dilakukan secara rutin untuk meningkatkan keterampilan peserta pelatihan khususnya dalam bidang tata kecantikan kulit. Target yang ditetapkan dalam pengabdian masyarakat Iptek bagi Bina Masyarakat (IbBM) ini adalah untuk memberikan pelatihan kepada masyarakat di Kota Tasikmalaya melalui program $\mathrm{P} 4 \mathrm{~K}$ sehingga masyarakat khususnya ibu-ibu memperoleh pengetahuan dan keterampilan guna meningkatkan pendapatan keluarga. Tim pelaksana dalam pengabdian IbBM ini sebanyak tiga orang yang merupakan dosen jurusan pendidikan masyarakat FKIP UNSIL.

Kata Kunci: Pemberdayaan Masyarakat, Pelatihan, Tasikmalaya
\end{abstract}

ABSTRACT
Community empowerment through this skin beauty training aims to improve community knowledge and skills in the City of Tasikmalaya through programs to improve education and family income (P4K). The results showed that most of the trainees expected this training to be carried out routinely to improve the skills of trainees, especially in the field of skin beauty. The target set in the community service of Science and Technology for Community Development (IbBM) is to provide training to the community in the City of Tasikmalaya through the P4K program so that the community, especially mothers, obtain knowledge and skills to increase family income. The implementing team in this IbBM service were three people who were lecturers at the FKIP UNSIL community education department. Keywords: Community Empowerment, Training, Tasikmalaya 


\section{PENDAHULUAN}

Peningkatan pendapatan keluarga sudah banyak dilakukan pemerintah, akademisi maupun swasta melalui berbagai kegiatan pendidikan maupun pelatihan. Pengabdian ini dilakukan untuk menjadi salah satu upaya pendukung bagi kemajuan masyarakat khususnya di bidang pendidikan dan keterampilan keluarga guna meningkatkan pendapatan keluarga. Pendapatan keluarga merupakan jumlah penghasilan riil dari seluruh anggota rumah tangga yang digunakan untuk memenuhi kebutuhan bersama maupun perseorangan dalam rumah tangga. Pendapatan keluarga erat kaitannya dengan kesejahteraan dan konflik keluarga. Salah satu indikator tingkat kesejahteraan keluarga diukur dari tingkat pendapatan. Tingkat pendapatan yang tinggi memberi peluang lebih tinggi bagi keluarga dalam memilih bahan pangan baik jumlah maupun jenisnya (Sari, A. 2012). Begitupun sebaliknya jika pendapat keluarga rendah maka akan menyebabkan status ekonomi keluarga yang rendah. Papp et.al (2009) melaporkan hasil penelitiannya bahwa pendapatan keluarga erat kaitannya dengan konflik keluarga. Hal ini sejalan dengan penelitian terdahulu yang mengungkapkan bahwa keluarga dengan struktur ekonomi rendah dan struktur keluarga (orang tua tunggal) akan membatasi peluang kesejahteraan keluarga dan meningkatkan singkat stres keluarga sehingga mempengaruhi kualitas hidup keluarga (Bailey et al., 2005; Fujiura \& Yamaki, 2000; Parish et al., 2008).

Burhanudin, et.al (2015) menyebutkan bahwa pendapatan keluarga dapat bersumber dari, usaha sendiri (wiraswasta), bekerja pada orang lain, dan hasil dari milik (aset). Pendapatan keluarga diyakini mampu membantu mewujudkan kesejahteraan keluarga, sehingga hal ini menjadi faktor pendorong bertambahnya jumlah partisipasi kerja di Kota Tasikmalaya, khususnya dalam bidang jasa kemasyarakatan. Berdasarkan data statistik Kota Tasikmalaya (2017) jumlah angkatan kerja di Kota Tasikmalaya pada tahun 2015 meningkat menjadi 62,59 persen, dan 22 persennya bekerja dalam bidang jasa kemasyarakatan. Tata kecantikan kulit merupakan salah satu jenis usaha dalam bidang jasa kemasyarakatan yang banyak ditemui di masyarakat terutama dalam usaha salon kecantikan. IbBM ini dilakukan dengan memberikan pelatihan tata kecantikan kulit pada masyarakat dalam rangka mendukung program peningkatan pendidikan dan pendapatan keluarga (P4K) di Kota Tasikmalaya. Kegiatan ini merupakan rangkaian kegiatan awal untuk mewujudkan masyarakat berdaya sehingga mampu memperoleh pendapatan keluarga ataupun pendapatan tambahan secara mandiri. Materi yang diajarkan dalam pelatihan pertama ini adalah materi "junior beautycian" dengan sasarannya adalah ibu-ibu yang belum memiliki pengetahuan dan keterampilan dalam bidang tata kecantikan kulit. Oleh karena itu pelatihan ini diberikan kepada masyarakat dalam rangka mendukung pembangunan dan pendapatan masyarakat melalui pendidikan. Melalui kegiatan pengabdian pada masyarakat ini diharapkan:

1. Meningkatkan keterampilan masyarakat dalam bidang tata kecantikan kulit serta para peserta pelatihan dapat mengaplikasikannya dalam kehidupan sehari-hari.

2. Keterampilan dan pengetahuan yang tata kecantikan kulit yang diperoleh dari pelatihan ini diharapkan dapat menjadi salah satu sumber pendapatan masyarakat guna menunjang pendapatan keluarganya. 
3. Peserta pelatihan mampu memanfaatkan sumber daya yang ia miliki sehingga mendorongnya untuk mandiri dan berwirausaha.

Jenis luaran yang dihasilkan dari pelatihan tata kecantikan kulit ini yaitu pemerolehan pengetahuan dan keterampilan dasar dalam bidang tata kecantikan kulit (junior beautycian).

\section{METODOLOGI}

Metode pelaksanaan kegiatan pengabdian pada masyarakat ini secara jelas dapat dilihat dalam gambar (2.1) berikut ini:

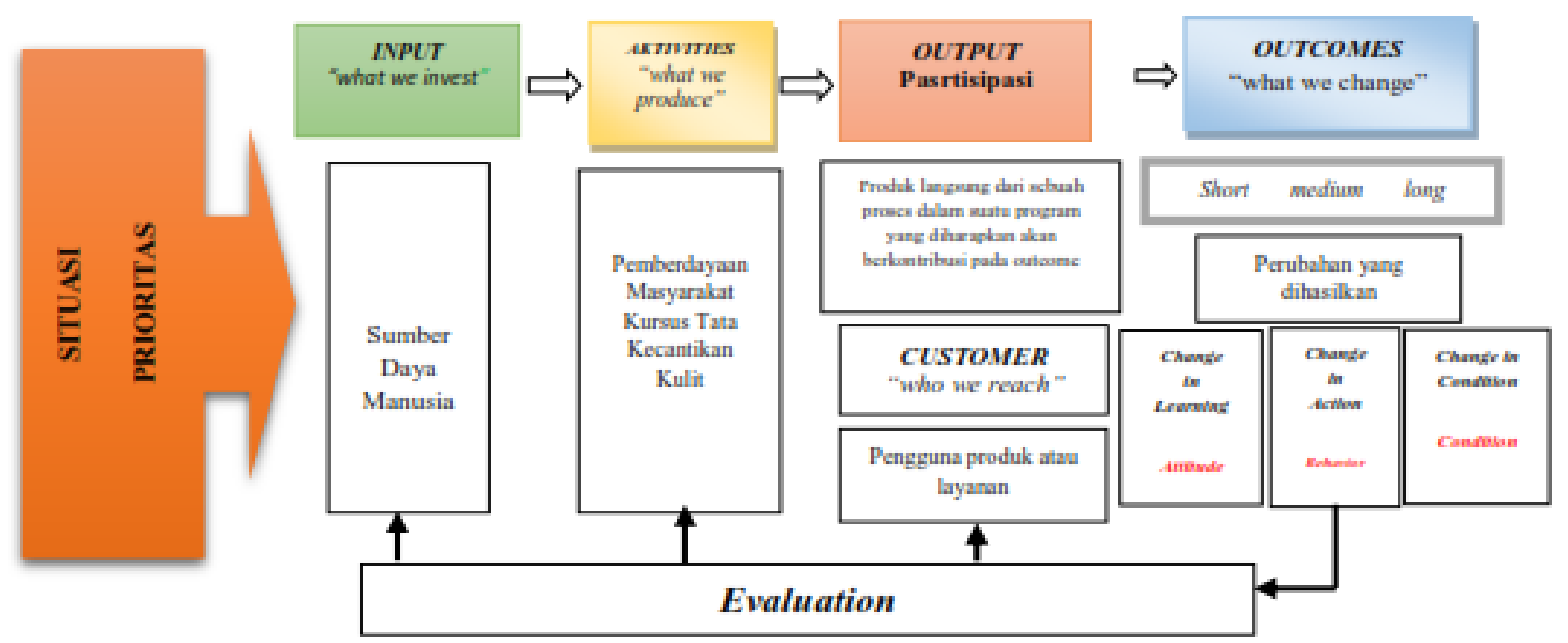

Gambar (2.1) Logic Model Pemberdayaan Masyarakat

Permasalahan prioritas mitra yang disepakati adalah sebagai berikut: a) pendampingan masyarakat dalam merubah mindset (pola pikir) masyarakat dalam memandang keterampilan tata kecantikan kulit sebagai salah satu peluang usaha; b) perlunya dibentuk lembaga konsultasi yang mewadahi alumni dalam pencarian informasi lowongan kerja; c) pentingnya peningkatan pengetahuan masyarakat dalam menciptakan kreativitas berfikir untuk memanfaatkan peluang usaha dalam tata kecantikan kulit; d) perlunya pendampingan motivasi ekstrinsik dari lembaga kursus kepada alumni kursus tata kecantikan kulit didalam menciptakan peluang usaha dari keterampilan yang diperoleh selama kegiatan pemberdayaan masyarakat; serta e) memfasilitasi adanya kerjasama baik dengan klinik kecantikan ataupun instansi yang membutuhkan tenaga kerja profesional dibidang jasa kecantikan kulit.

Dalam rangka mencapai tujuan pengabdian pada masyarakat ini metode yang digunakan adalah penyampaian materi kompetensi jasa kesehatan dan keselamatan kerja serta materi pengenalan alat dan bahan dalam jasa kecantikan. Dilanjutkan dengan materi mengenai tata cara komunikasi dengan pelanggan. Kemudian diikuti dengan praktik "junior beautycian . Adapun prosedur kerja atau desain pengabdian yang dilaksanakan dalam rangka perwujudan IbBM ini adalah sebagai berikut: 


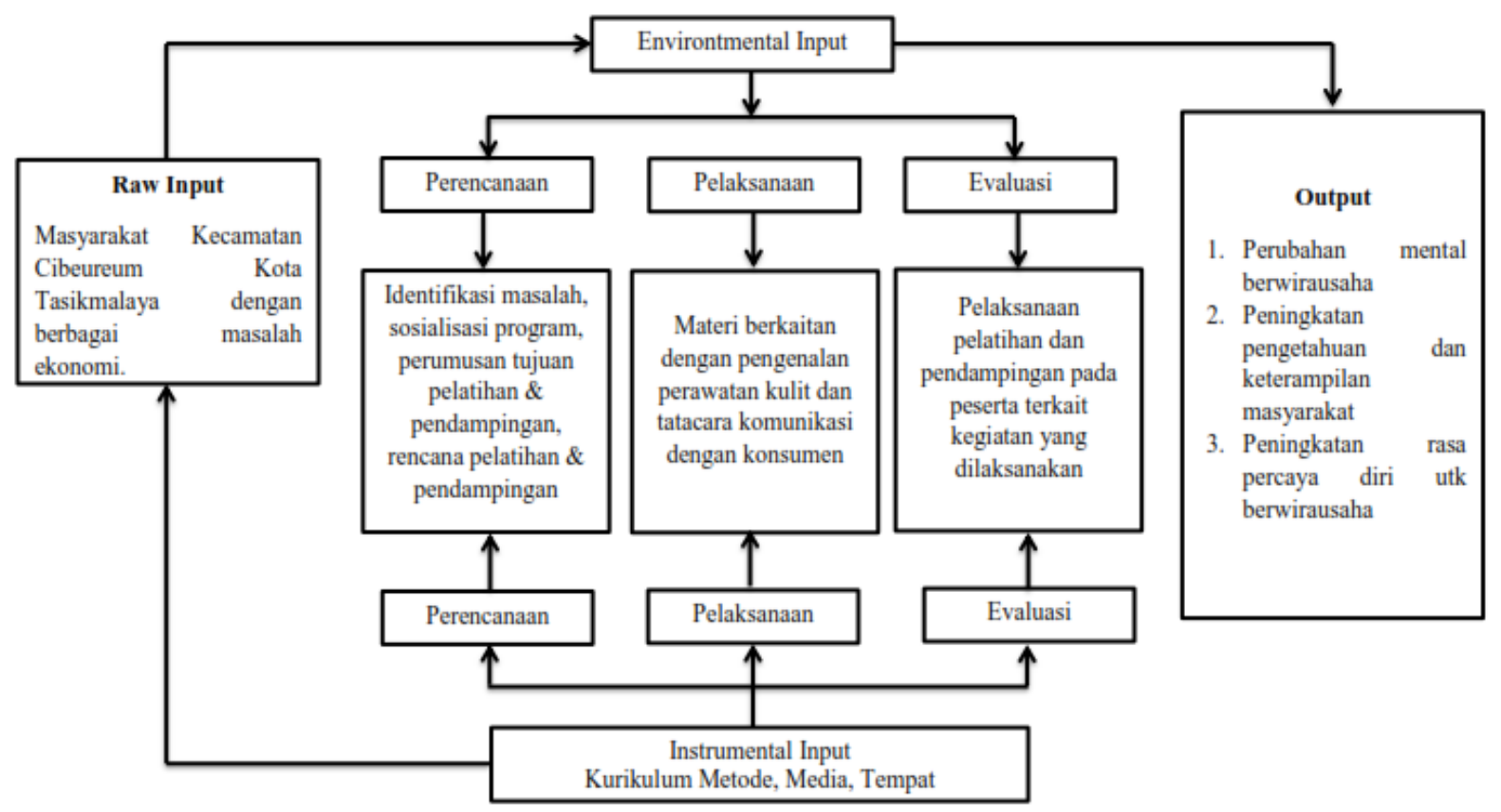

Gambar (2.2) Desain Pengabdian Pada Masyarakat

Partisipasi mitra dalam kegiatan pemberdayaan pada masyarakat ini diantaranya yaitu:

a) Mitra mendukung sepenuhnya terkait dengan kerjasama dalam peningkatan pengetahuan, keterampilan dan pendidikan pada peserta tata kecantikan kulit, dengan memberikan kesempatan tim pengabdian dari Jurusan Pendidikan Masyarakat dalam menerapkan program peningkatan pendidikan dan pendapatan keluarga.

b) Mitra memfasilitasi tempat dan sarana prasarana didalam implementasi kegiatan peningkatan keterampilan dan pengatahuan dalam mencetak peningkatan pendapatan keluarga.

c) Dalam pelaksanaan kegiatan pemberdayaan LKP Yuwita menyiapkan tiga instruktur yang akan mendampingi pelaksanaan pemberdayaan masyarakat pada peserta kursus tata kecantikan kulit.

\section{HASIL DAN PEMBAHASAN}

Kegiatan pengabdian ini dilaksanakan pada tanggal 25 Juli 2019 bertempat di LKP Yuwita Kota Tasikmalaya. Pada pelaksanaannya diawali dengan penyampaian materi mengenai kompetensi jasa kesehatan dan keselamatan kerja, pengenalan alat dan bahan dalam jasa kecantikan, dan materi tentang tata cara komunikasi dengan pelanggan. Pengabdian melalui pelatihan ini ditujukkan bagi masyarakat yang berminat dalam bidang tata kecantikan kulit untuk menjadi "junior beautycian". Peserta pelatihan yang menjadi sasaran pengabdian masyarakat melalui pelatihan tata kecantikan kulit dalam program peningkatan pendidikan dan pendapatan keluarga sebanyak 33 orang peserta.

Pada tahap kedua setelah berlangsungnya penyampaian materi, maka dilanjutkan kepada sesi praktik. Sarana yang gunakan dalam pelatihan ini adalah sarana perangkat salon yang 
tersedia di lembaga mitra yaitu LKP Yuwita yang berlokasi di Jln. Letjen Mashudi (Lanud Wiriyadinata) Cibeureum Kota Tasikmalaya.

Adapun durasi materi yang disampaikan adalah sebagai berikut:

- Materi kompetensi jasa kesehatan kerja (2 x 120 menit)

- Materi pengenalan alat dan bahan dalam jasa kecantikan (2 x 120 menit)

- Materi tentang tata cara komunikasi dengan pelanggan ( 2 x 120 menit)

\section{KESIMPULAN DAN SARAN}

Berdasarkan hasil kegiatan pengabdian pada masyarakat melalui pelatihan tata kecantikan kulit dalam program peningkatan pendidikan dan pendapatan keluarga ( $\mathrm{P} 4 \mathrm{~K})$ ini dapat disimpulkan bahwa hampir sebagaian besar peserta pelatihan mengharapkan pelatihan ini dilakukan secara rutin untuk meningkatkan keterampilan peserta pelatihan khususnya dalam bidang tata kecantikan kulit.

\section{DAFTAR PUSTAKA}

Bailey, D. B., Hebbeler, K., Spiker, D., Scarborough, A., Mallik, S., \& Nelson, L. (2005). Thirty-sixmonth outcomes for families of children who have disabilities and participated in early intervention. Pediatrics,116,1346-1352.

BPS Kota Tasikmalaya. Penduduk dan Ketenaga Kerjaan di Kota Tasikmalaya. Tersedia [Online]: https://tasikmalayakota.bps.go.id/ Retrieved 02 September 2019

Burhanudin, et.al., (2015). Faktor-Faktor Yang Mempengaruhi Pendapatan Keluarga Di Kecamatan Banyuwangi Kabupaten Banyuwangi. Program Studi Ekonomi Pembangunan, Jurusan Ilmu Ekonomi dan Studi Pembangunan, Fakultas Ekonomi, Universitas Jember. Artikel Ilmiah Mahasiswa. Tersedia [Online]: http://repository.unej.ac.id/bitstream/handle/123456789/64664/MUHAMMAD\%20BUR HANUDIN.pdf?sequence=1 Retrieved 02 September 2019

Fujiura, G. T., \& Yamaki, K. (2000). Trends in demography of childhood poverty and disability. Exceptional Children, 66, 187-199.

Papp, L. M., Cummings, E. M., \& Goeke-Morey, M. C. (2009). For richer, for poorer: Money as a topic of marital conflict in the home. Family Relations, 58(1), 91-103. doi:10.1111/j.1741-3729.2008. 00537.x.

Parish, S. L., Rose, R. A., Grinstein-Weiss, M., Richman, E. L., \& Andrews, M. E. (2008). Material hardship in U.S. families raising children with disabilities. Exceptional Children,75,71-92.

Sari, A. (2012). Pendapatan Keluarga, Pengetahuan, Sikap, Konsumsi Serta Status Gizi Anak Keluarga Peternak Ikan Lele (Clarias Gariepinus). Departemen Gizi Masyarakat Fakultas Ekologi Manusia Institut Pertanian Bogor. Skripsi. Tersedia [Online]: https://repository.ipb.ac.id/jspui/bitstream/123456789/63087/1/I12anr.pdf Retrieved 02

September 2019 